\title{
Justice of Spatial Space in The Indonesian Law System
}

\author{
Nugraha Pranadita ${ }^{1}$, Imas Rosidawati ${ }^{2}$, Tansah Rahmatullah ${ }^{3}$ \\ \{nugrahapranadita@uninus.ac.id ${ }^{1}$, imasrosidawati@uninus.ac.id², \\ tansah_rahmatullah@uninus.ac.id $\left.{ }^{3}\right\}$ \\ ${ }^{1,2,3}$ Master of Law Studies Program Post-Graduate School, Nusantara Islamic University, \\ Bandung, Indonesia
}

\begin{abstract}
It is now known that parts of space that are right above the equator at an altitude of $35,786 \mathrm{~km}(22,236$ miles) have high economic value as an ideal place to place man-made satellites for various purposes. This is due to the natural characteristics of the earth as a gift from God to the Indonesian people. There is no regulation in the 1945 Constitution of the Republic of Indonesia. Four times the amendments to the constitution in question have not been able to provide legal protection against the grace of God. Through this research, it is expected that there will be a better understanding of God's grace to the Indonesian people in the form of spatial justice and legal protection in Indonesia's positive legal system. This research is a normative legal research using secondary data as the primary legal material. The conclusions of this study are; that spatial justice in the form of space using an approach to the theory of natural law is a gift from God to the Indonesian people. By using a natural law approach that comes from logical human reasoning, spatial justice is implicitly part of the justice contained in positive law, namely legislation related to space. That thus spatial justice becomes a part of justice contained in the Indonesian legal system.
\end{abstract}

Keywords: justice, spatial, legal, and space

\section{INTRODUCTION}

The existence and development of the problems of space law that directly influence the rules of space law are due to the activities of countries in air space and space for various purposes [1]. Real-time exploration began in 1957 when the Soviet Union launched the Sputnik I satellite, while the regulations governing the use of space began with the resolution of the United Nations which gave birth to the Outer Space Treaty in 1967 [2]. Initially only countries that used space for various purposes. In its development, space is currently used for commercial purposes (commercialization of space [3]) in order to obtain economic benefits both by the state and by the private sector [4]. One form of commercial use of space by the private sector at this time which is quite interesting for the public is for space tourism activities [5]. The use of space by various parties ultimately creates a risk that is caused by the presence of space junk that endangers the spacecraft [6]. When the state realizes that space has economic value other than strategic values for the interests of national defense and security, at that time the state needs legal instruments to protect its interests [7]. 
People of nations in the world today position space problems in a position not under the jurisdiction of any country, res communis or the common heritage of all mankind [8]. In fact, in space there are positions that have economic value so that they become contested by the international community who have superiority in technology and finance to master them. Caused by various natural factors, the space area above the equator has a special feature that is because a satellite placed above the equator at a certain height $(35,786 \mathrm{Km}$ above the earth's surface [9]) will have a rotation time equal to the Earth's rotation time so that the satellite remains stay in place.

In essence the territory of a country is three-dimensional in nature which includes land, oceans and space which is a unified whole [10]. For most countries whose territory is on the equator, due to various reasons, both external and internal, they cannot utilize natural resources in the form of space space in order to improve the welfare of their communities. In this case the countries in question whose territory is located on the equator do not obtain spatial justice, which is related to the use of space which is geographically located above it. There needs to be a new international legal order that can distribute spatial justice in space fairly to countries in general size.

In the verse of the Qur'an it is stated that there is equality between the earth and the sky, and the position of the earth and sky facing each other (earth below and the sky above). "(He is) who made the earth a stretch for you and the sky as a roof, ...", QS. Al-Baqarah (2): 22. "God who created the seven heavens and from (creation) the earth is also similar ...", QS. AthThalaq (65): 12. It also said that; "And do the unbelievers not know that the heavens and the earth both used to be fused, ...", QS. Al-Anbiya (21): 30.

Indonesia is a legal state [11] that adheres to the civil law legal tradition. For Indonesia, the implementation of the civil law legal tradition is not merely a choice, but rather a historical legacy of the process of forming the Indonesian state itself. This is closely related to the fact that Indonesia was once part of a Dutch colony that followed the civil law law tradition. After more than 73 years of independent Indonesia, the civil law legal tradition which initially was an inheritance has succeeded in transforming itself into a logical choice of the Indonesian nation, so that its binding power is based on pragmatic truths.

Civil law legal traditions place a written constitution (constitution) as a written basic law where all kinds of organic laws originate. What is meant by organic law here is a law whose process of formation is ordered by the constitution (constitution) or by another law [12] that is at least level or equivalent. Regarding the existence of space law in Indonesia, there are problems because the regulation is not found in the written constitution of the Indonesian state.

It is true "the earth and water and the natural wealth contained in it are controlled by the state and are used for the greatest prosperity of the people" [13]. It is true that the prosperity or welfare of the people of Indonesia is part of the goal of establishing an Indonesian state government based on independence, lasting peace and social justice [14]. That thus the welfare of the Indonesian people is part of the purpose of the existence of law in Indonesia, which originates from (philosophy) Pancasila as a source of all sources of law in Indonesia.

Implicitly the purpose of law in Indonesia is the same as the goal of establishing the Indonesian government itself. One of the traditional legal objectives is justice, which when compared with the objective of forming the Indonesian government, justice here is not legal justice, but social justice for all Indonesian people. Qualitatively, social justice is easier to define than legal justice. While quantitatively, social justice is easier to measure than legal justice. According to Immanuel Kant; "Noch suchen die Juristen eine Definition zu ihrem Begriffe von Recht" (still law scholars are looking for a definition of law) [15]. If the legal 
definition is so difficult to agree on, of course the definition of legal justice will be even more difficult to agree on. What about spatial justice?

\section{METHOD}

This paper is a report on the results of doctrinal law research [16] also known as library legal research because it uses secondary data which is generally found in a library, data storage, and or other places that have the same function. Secondary data that has conformity with this study are then categorized or grouped into primary legal materials, secondary legal materials, and tertiary legal materials. Primary legal material is the main ingredient of this research, while secondary legal materials and tertiary legal materials are more complementary legal materials. As is generally the case with research, this study also aims to find the truth of research, namely pragmatic truth [17] where the truth of all things is true as long as the truth can be proved to be true.

\section{RESULT AND DISCUSSION}

As time went on, space existence became more important for countries in the world, especially for the purposes of communication and information, as well as the development of science. In this case not all countries in the world have the ability to explore or exploit the potential possessed by space. This is because the use of space is an activity that requires large costs, high technology and high risk as well, where not many countries in the world are able to do so.

Not all regions of space have the same characteristics. For example, the space region above the equator naturally has a feature because at an altitude of 35,786 Km (Orbit Geostationer [18]) can be occupied by man-made satellites with a relatively stable position (silent), so the satellite placed in that position will remain relatively in place at all times so that the satellite can function as it should be optimally. This is caused by the natural conditions of the equator itself where the length of the circle of the earth that surrounds the equator is longer than the length of the circle of the earth that passes through the polar region. The earth is not completely round, but is more convex in the equator. According to computer simulations and analyzes conducted by Scott Tremaine from the Institute for Advanced Study in Princeton, New Jersey and Tomer Yavetz from Princeton University, the shape of the earth is not perfectly round, flatter on the poles and fatter at the equator. Gravity in the fatter parts of the earth in the equator can keep the satellite in position. Indonesia is the longest-traversed country in the world, covering $13 \%$ of Indonesia's territory [19]. It is proper for Indonesia to benefit from God's gift in the form of spatial justice.

Spatial justice is composed of two independent words, namely; justice and spatial. According to the meaning of the word, justice is; "The nature (deeds, treatment, etc.) are fair" [20], while fair is; "Equally heavy; not heavy-side; impartial; side to the right; hold on to the truth; duly; not arbitrary". The spatial is; "With regard to space or place" [21]. Based on the meaning of the word, spatial justice can be conceptualized as a fair act related to a particular place. In this study, what is meant by a certain place is a place that is generally known or referred to as space.

Space existence is natural and free from human intervention. Space is a gift that exists by itself so that only humans can use it to fulfill their needs. This approach to thinking related to space must use a natural law approach derived from God and / or an approach to natural law originating from the human mind which is certainly universal. The thought of a natural law approach originating from God will direct our thoughts towards more religious thoughts. 
Meanwhile, the legal approach derived from the universal human mind will direct our thinking towards logical, logical and sociologically logical thinking. Included in sociologically logical thinking are economically logical thoughts.

The approach to natural law originating from the human mind in Indonesia related to the existence of space can be done using the approach of legislation related to space, including; (1) Law of the Republic of Indonesia Number 5 of 1960 concerning Basic Principles of Agrarian Affairs, and (2) Law of the Republic of Indonesia Number 21 of 2013 concerning Insitutions. The two laws according to the order of the laws and regulations in Indonesia are laws that are organic in nature, namely laws established to implement the constitution. But in fact, in the 1945 Constitution of the Republic of Indonesia, there is no single article that gives an arrangement related to the existence of space. The historical background for the formation of the two laws and regulations is also different. The Basic Agrarian Law was made during the "old order" leadership, while the space law was created during the "reform order" leadership.

Both of these, the absence of space regulation in the constitution and the different times at the time of the establishment of the law which was intended, have actually caused differences in thinking related to space as follows : 1) According to the Agrarian Basic Law; space is space on earth and water (Article 1 number 6). Whereas according to the Kentariksaan Law; space is space and its contents that are outside the airspace that surrounds and encircles the airspace (Article 1 number 1). Obviously the two laws have different definitions regarding the space position; 2) According to the Agrarian Basic Law; space is Indonesia's national wealth as a gift from God, so it is the right of the Indonesian people to have it (Article 1 point 2). Whereas according to the Space Law; space is a shared area that can be utilized for the benefit of all countries (Article 3 paragraph 1); 3) According to the Agrarian Basic Law; the relationship between the Indonesian people and space is a lasting relationship (Article 1 point 3). Whereas according to the Space Law; the relationship between Indonesia and space is not enduring because it must submit to international agreements (General explanation of the second paragraph); 4) According to the Basic Agrarian Law; space is controlled by the state (Article 2 number 1). Whereas according to the Space Law; mastery of space must be subject to international agreements (General explanation of the second paragraph); 5) According to the Agrarian Basic Law; sources of space law are customary law, positive law, and religious law (Article 5). As according to the Space Law; the source of space law is an international agreement (General Explanation); 6) According to the Basic Agrarian Law; only Indonesian citizens who have a complete relationship with space (Article 9 paragraph 1). Whereas according to the Space Law; foreign party that has obtained permission to have a relationship with space (Article 5 letter d).

Some of the fundamental differences contained in the Law of the Republic of Indonesia Number 5 of 1960 concerning Basic Regulations on Agrarian Principles with the Law of the Republic of Indonesia Number 21 of 2013 concerning Space provide an illustration to us that in the Basic Agrarian Law the arrangement is general and in matters that are fundamental (fundamental) only, do not provide arrangements that are more related to the technical problems of implementation. In this case, the more technical regulations relating to space will be regulated in the implementing regulations of the law which can be in the form of Government Regulations or Presidential Regulations.

Meanwhile in the Law of the Republic of Indonesia Number 21 of 2013 concerning Space, the arrangement is more technical in nature because there are many technical terms, not just legal terms. The arrangements contained in the law can be relatively directly implemented without the need to wait for the implementation regulations. In the space law, there has also been the distribution of authority to institutions or agencies related to space activities. There is 
no regulation in the Law of the Republic of Indonesia Number 5 of 1960 concerning Basic Regulation on Agrarian Principles.

It is interesting to see whether between the two laws there is a dualism of regulating space law, and how the relationship between the two laws is related to regulating space issues. Understanding of this can be built using generally accepted legal principles as a means to conduct analysis. This can be described as follows: 1) Principle lex specialis derogat legi generalis (the provisions of special regulations or laws exclude general provisions). Law of the Republic of Indonesia Number 5 of 1960 concerning Basic Regulations on Agrarian Principles provides general arrangements relating to space, meanwhile the Law of the Republic of Indonesia Number 21 of 2013 concerning Space provides technical arrangements (implementing regulations) related to space. Technical arrangements cannot be equated with special arrangements. Based on this, it can be seen that the use of Principle lex specialis derogat legi generalist to understand the correlation between the Law of the Republic of Indonesia Number 5 of 1960 concerning Basic Regulation on Agrarian Principles and Law of the Republic of Indonesia Number 21 of 2013 concerning Space is irrelevant. The provisions of general laws and regulations cannot be equated with the provisions of the basic legislation. According to the meaning of the word, the general word is; "Concerning all or all; as a whole, it does not involve the specific (certain) only. While the meaning of the main words is; "principle; basic; essence; center (which is a point of concern and so on); especially; very important: ". It can be said that the Basic Agrarian Law regulates basic matters, not regulating general matters relating to the regulation of space, because the arrangements contained in the agrarian principal law are fundamental. Whereas the Space Law cannot be said to be a special statutory regulation. This is due to kareka according to the meaning of the word, specifically is; "typical; special; not general: ", while the substance of the Space Law is more technical in nature. Based on this description, it can be understood that the principle of lex specialis derogat legi generalis is irrelevant to be used to understand the correlation between the Basic Agrarian Law and the Law of Space because the two laws have different substances; 2) Principle lex superior derogat legi inferior (provisions of regulations or laws that have a higher degree of prioritization / mention than provisions that have a lower degree). According to the provisions of the Republic of Indonesia Law Number 12 of 2011 concerning the Establishment of Legislation, Article 7 paragraph (1), Law of the Republic of Indonesia Number 5 of 1960 concerning Basic Regulations on Agrarian Principles with the Law of the Republic of Indonesia Number 21 Year 2013 About the Alliance the hierarchy is the same as the law. Thus the principle cannot be applied lex superior derogat legi inferior; 3) Principle lex post teriori derogat legi priori (the provisions of the new laws or regulations exclude / remove the entry into force of the provisions of the old law governing the same legal material). That it is true that the Basic Agrarian Law is longer than the Law on Space, but the material (substance) of the two laws is actually different. Judging from the naming of the law in question; The Law of the Republic of Indonesia Number 5 of 1960 concerning Basic Regulations on Agrarian Principles basically regulates the problem of land (agrarian), while the Law of the Republic of Indonesia Number 21 Year 2013 concerning Space is essentially regulating the problem of space (space). That accordingly the use of the lex post teriori derogat legi priori principle is irrelevant to understanding the correlation between the two laws in question.

Based on the description above it can be understood that the use of the principle of lex specialis derogat legi generalis, the principle of lex superior derogat legi inferior, and the principle of lex post teriori derogat legi priori cannot explain the correlation between the provisions of legislation related to space contained in the Act Republic of Indonesia Number 5 
of 1960 concerning Basic Agrarian Principles and Law of the Republic of Indonesia Number 21 of 2013 concerning Space. Because the legal principle cannot explain the correlation between the two laws relating to space, then understanding related to space must use philosophical thinking. Because the basic philosophy of the Indonesian nation is Pancasila, the precepts contained in the Pancasila can be used to analyze the correlation referred to in relation to the title of this paper.

The spatial justice referred to in the title of this paper is justice related to the existence of space within the Indonesian legal system, whose arrangements are included in the Basic Agrarian Law and the Law on Space. Space is acknowledged to be the creation of God Almighty (the consideration of the letter a the Law of Space) and is the gift of God Almighty (Article 1 number 2 of the Basic Agrarian Law) to the Indonesian people who acknowledge the existence of God as meant by the first principle of Pancasila, namely ; "Belief in the one and only God". Thus the first real principle of the Pancasila becomes the basic philosophy of the existence of spatial justice related to space which has its arrangement in Indonesian positive law. In this case the first principle of Pancasila has the ability to transform ownership of space according to a philosophical view into a law that is ius constitutum [22] so that it can present spatial justice for the Indonesian people.

\section{CONCLUSIONS}

Based on the description above, it can be concluded that spatial justice in the form of space using an approach to the theory of natural law is a gift from God to the Indonesian people. Then by using Pancasila philosophical thinking it can be understood implicitly that spatial justice is a part of justice contained in positive law, namely legislation related to space. That thus spatial justice becomes a part of justice contained in the Indonesian legal system.

\section{REFERENCES}

[1] Aryuni Yuliantiningsih, Aspek Hukum kegiatan Wisata Ruang Angkasa (Space Tourism) Menurut Hukum Internasional, Jurnal Dinamika Hukum, Vol. 11, No. 1, 2011

[2] Marthinus Omba, Prinsip Kebebasan Di Ruang Angkasa Menurut "Outer Space Treaty 1967” Dan Perkembangannya, Jurnal Hukum dan Pembangunan, No. 4, Tahull XXIV, p. 335,1994

[3] Agus Pramono, Urgensi Penataan Hukum Keruangangkasaan Dalam Kerangka Kepentingan Nasional Negara Berkembang, Jurnal Masalah-Masalah Hukum, Jilid 48 No.1, p-ISSN : 2086-2695, e-ISSN : 2527-4716, p. 49, 2019

[4] Sri Wartini, Pertanggungjawaban Negara Dalam Kegiatan Komersiil Ruang Angkasa Yang Dilakukan Oleh Perusahaan Swasta, Jurnal Hukum, Vol. 12, No. 28, p. 116, 2005

[5] Muhammad Megah, Kajian Aspek Hukum Internasional Mengenai Kegiatan Wisata Antariksa, Jurnal Analisis Dan Informasi Kedirgantaraan, Vol. 9, No. 2, p. 133, 2012

[6] Errya Satrya, Sampah Antariksa Masalah Di Masa Kini Dan Esok, Jurnal Berita Dirgantara, Vol. 10, No. 3, p. 72, 2009

[7] Endang Puji Lestari, Rekonsepsi Hak Penguasaan Negara Atas Wilayah Udara Di Tengah Kebijakan Liberalisasi Penerbangan, Jurnal Rechts Vinding, Vol. 4, No. 2, ISSN 2089-9009, p. 328, 2015

[8] Agit Yogi Subandi, Tanggung Jawab Perusahaan Multinasional Dalam Kegiatan Keruangangkasaan Menurut Hukum Internasional Dan Hukum Ruang Angkasa, Jurnal Bina Mulia Hukum, Vol. 1, No. 2, P-ISSN: 2528-7273 E-ISSN: 2540-9034, p. 152, 2017 
[9] Djorghy Reo Angelo Bahar, Penempatan Satelit Di Ruang Angkasa Menurut Hukum Internasional, Jurnal Lex et Societatis, Vol. III, No. 7, p. 64, 2015

[10] Danang Risdiarto, Penegakan Hukum Terhadap Pelanggaran Wilayah Udara Yurisdiksi Indonesia Oleh Pesawat Terbang Asing Tidak Terjadwal, Jurnal Rechts vinding, Vol. 5, No. 1, ISSN 2089-9009, p. 71, 2016

[11] Undang-Undang Dasar Negara Republik Indonesia Tahun 1945, Pasal 1 ayat (3)

[12] KBBI online, Undang-Undang Organik, Retrieved April 23, 2019 from https://kbbi.kemdikbud.go.id/entri/undang-undang\%20organik

[13] Undang-Undang Dasar Negara Republik Indonesia Tahun 1945, Pasal 33 ayat (3)

[14] Op,cit., Pembukaan, Alinea ke-Empat

[15] C.S.T. Kansil, dan Christine S.T Kansil. Pengantar Ilmu Hukum Indonesia, Rineka Cipta, Jakarta, p. 30, 2011

[16] Soetandyo Wignjosoebroto dikutif dari Bambang Sunggono, op.cit., p. 42. Lihat juga Salim HS. dan Erlies Septiana Nurbani, op.cit., p. 11.

[17] Johnny Ibrahim, Teori \& Metodologi Penelitian Hukum Normatif, Bayumedia Publishing, Malang, p. 119, 2012

[18] Anjar Supriadhie, Rezim Hukum Khusus Atas Orbit Geostasioner (GSO) (Prospek dan Tantangan), Jurnal Pandecta, Vol. 13, No. 1, ISSN 1907-8919 (Cetak), ISSN 2337-5418 (Online), p. 64, 2018

[19] Rozi Maiza Putri, Kepentingan Rusia Bekerjasama Dengan Indonesia Dalam Bidang Teknologi Antariksa, Jurnal JOM FISIP, Vol. 3, No. 2, p. 4, 2016

[20] KBBI online, Keadilan, Retrieved April 24, 2019 from https://kbbi.kemdikbud.go.id/entri/keadilan

[21] KBBI online, Spasial, Retrieved April 24, 2019 from https://kbbi.kemdikbud.go.id/entri/spasial

[22] Tri Jata Ayu Pramesti, Arti Ius Constitutum dan Ius Constituendum, Retrieved April 24, 2019 from https://www.hukumonline.com/klinik/detail/ulasan/lt56777c031 ec1c/arti-iusconstitutum-dan-ius-constituendum 